\title{
Syntaxin-4 Is Localized to the Apical Plasma Membrane of Rat Renal Collecting Duct Cells: Possible Role in Aquaporin-2 Trafficking
}

\author{
Béatrice Mandon, ${ }^{*}$ Chung-Lin Chou, ${ }^{*}$ Søren Nielsen, ${ }^{\ddagger}$ and Mark A. Knepper ${ }^{\star}$ \\ * Laboratory of Kidney and Electrolyte Metabolism, National Heart, Lung, and Blood Institute, National Institutes of Health, Bethesda, \\ Maryland 20892-1598; and ${ }^{\ddagger}$ Department of Cell Biology, Institute of Anatomy, University of Aarhus, Aarhus, Denmark
}

\begin{abstract}
To evaluate the possible role of a putative vesicle-targeting protein, syntaxin-4, in vasopressin-regulated trafficking of aquaporin-2 water channel vesicles to the apical plasma membrane of renal collecting duct cells, we have carried out immunoblotting, immunocytochemistry, and reverse transcription (RT)-PCR experiments in rat kidney. Immunochemical studies used an affinity-purified, peptide-directed polyclonal antibody to rat syntaxin-4. Immunoblots using membrane fractions from inner medullary collecting duct (IMCD) cell suspensions revealed a solitary protein of 36 $\mathrm{kD}$, the expected molecular mass of syntaxin-4. This protein was enriched in a plasma membrane-enriched membrane fraction from IMCD cells. Immunoperoxidase immunocytochemistry in $\mathbf{0 . 8 5}-\mu \mathrm{m}$ cryosections from rat inner medulla revealed discrete labeling of the apical plasma membrane of IMCD cells. RT-PCR demonstrated the presence of syntaxin-4 mRNA in microdissected IMCD segments, confirmed by direct sequencing of the PCR product. In addition, RT-PCR experiments demonstrated syntaxin-4 mRNA in glomeruli, vasa recta, connecting tubules, and thin descending limbs of Henle's loops. The demonstrated localization of syntaxin-4 in the apical plasma membrane of collecting duct principal cells, coupled with previous demonstration of syntaxin-4's putative cognate receptor VAMP2 in aquaporin-2-containing vesicles, supports the view that these proteins could play a role of aquaporin-2 vesicle targeting to the apical plasma membrane. (J. Clin. Invest. 1996. 98:906913.) Key words: syntaxin • collecting duct • vesicle-targeting receptors • water channel $\bullet$ aquaporin
\end{abstract}

\section{Introduction}

The peptide hormone, vasopressin, regulates water excretion in part through its action to increase the osmotic water permeability of the principal cells of the renal collecting duct $(\mathrm{CD})^{1}(1$, 2 ). This action is mediated by cAMP, whose intracellular levels increase as a result of binding of vasopressin to $V_{2}$ receptors. We

Address correspondence to Mark A. Knepper, M.D., Ph.D., National Institutes of Health, Building 10, Room 6N307, 10 Center Drive MSC 1598, Bethesda, MD 20892-1598. Phone: 301-496-3064; FAX: 301402-1443; E-mail: knep@helix.nih.gov

Received for publication 13 March 1996 and accepted in revised form 3 June 1996.

1. Abbreviations used in this paper: $\mathrm{CD}$, collecting duct; HS, highspeed; IM, inner medulla; KLH, keyhole limpet hemocyanin; LS, low-speed; OM, outer medulla; RT, reverse transcription; SNARE, SNAP receptor or vesicle-targeting receptor; VAMP, vesicle-associated membrane protein.

The Journal of Clinical Investigation

Volume 98, Number 4, August, 1996, 906-913 have recently demonstrated in isolated perfused collecting ducts that vasopressin increases osmotic water permeability of the principal cells by triggering translocation of aquaporin-2-containing vesicles to the apical plasma membrane (3). Similar observations have also been made recently in in vivo studies (4-6).

The molecular mechanisms responsible for targeting of aquaporin-2-containing vesicles to the apical plasma membrane are as yet unknown. One plausible paradigm has arisen largely on the basis of studies of the molecular mechanisms by which synaptic vesicles dock and fuse with plasma membrane (7-9), namely the "SNARE hypothesis." In this model, it has been proposed that specificity of docking and fusion in vesicular trafficking is mediated by specialized integral membrane proteins present in vesicles and in the target membrane which act as vesicle-targeting receptors, or so-called "SNAp REceptors" or "SNAREs" (7). Three such proteins have been identified in translocating vesicles, namely VAMP1 (vesicle-associated membrane protein-1 or synaptobrevin-1), VAMP2 (synaptobrevin-2), and cellubrevin. These have been termed "vSNAREs." We have demonstrated recently that VAMP2 or a closely related homologue is present in aquaporin-2-containing vesicles of collecting duct cells, suggesting that VAMP2 may function as a vesicle-targeting receptor for vasopressinregulated exocytosis of these vesicles (10). The presence of VAMP2 in water channel vesicles of collecting duct cells has also been demonstrated by Jo et al. (11) and Liebenhoff and Rosenthal (12). In addition, another VAMP isoform, cellubrevin, has been detected recently in rat inner medullary collecting duct (IMCD) cells and intracellular vesicles in these cells are colabeled with antibodies to cellubrevin and aquaporin-2 (13).

VAMPs or synaptobrevins are proposed to bind to cognate vesicle-targeting receptors in target membranes, which include several members of the syntaxin family and SNAP-25 $(9,14)$. These have been termed "t-SNAREs" (7). Among the known syntaxin isoforms, only syntaxin-1 and syntaxin- 4 bind VAMP2 with high affinity $(15,16)$. Thus, syntaxin-1 and syntaxin-4 could be considered candidates for a role in targeting of the aquaporin-2/VAMP2-containing vesicles to the apical plasma membrane in collecting duct cells. In contrast to syntaxin-1, which is expressed predominantly in the central nervous system, syntaxin- 4 is expressed in a variety of tissues including the kidney (14). Thus, we hypothesize that syntaxin-4 may be expressed in collecting duct cells where it could play a role in the targeting of aquaporin-2/VAMP2-containing vesicles to the apical plasma membrane of renal collecting duct cells. In this study, we address this hypothesis using immunoblotting, immunocytochemistry, and reverse transcription (RT)-PCR to localize syntaxin-4 and its mRNA within the kidney.

\section{Methods}

\section{Polyclonal antibodies}

To obtain a polyclonal antibody which specifically recognizes syntaxin-4, a 23-amino acid peptide corresponding to the amino termi- 
nus of the rat syntaxin-4 (with an added carboxy-terminal cysteine) was synthesized by standard solid peptide synthesis techniques yielding a sequence from the amino to carboxy termini of RDRTHELRQGDNISDDEDEVRVC. This sequence is distinct from the amino-terminal sequence of the other known syntaxins. A search of the available protein sequence data bases using the BLAST computer program revealed that this sequence is distinct from that of all other known eukaryotic proteins. The peptide was purified by HPLC and was conjugated to maleimide-activated keyhole limpet hemocyanin (KLH) via covalent linkage to the amino-terminal cysteine. Two rabbits were immunized with this conjugate using a combination of Freund's complete and incomplete adjuvants. One rabbit developed an ELISA titer $>1: 32,000$ before exsanguination and all subsequent studies were done with this antiserum (LL279). The antiserum was affinity-purified using a column on which $2 \mathrm{mg}$ of the same synthetic peptide was immobilized via covalent linkage to activated agarose beads (immunobilization kit No. 2; Pierce, Rockford, IL). An IgG fraction of the preimmune serum was purified on a protein A affinity column (Pierce) for use as a negative control in immunolabeling experiments.

To obtain a polyclonal antibody that specifically recognizes VAMP2 we used a synthetic-peptide approach similar to that described above for the syntaxin- 4 antibody. The sequence of the immunizing peptide from amino to carboxy termini was SATAATVPPAAPAGEGGC. This corresponds to the initial 17 amino acids of rat VAMP2 (17) with an added cysteine at the carboxy end to allow conjugation of the peptide to KLH or to agarose beads as described above. Two rabbits were immunized with the peptide-KLH conjugate. One developed an ELISA titer $>1: 8,000$ and all studies were done with this antiserum (LL220). The antiserum was affinity-purified before use as described above ( $\mathrm{IgG}$ concentration, $0.10 \mathrm{mg} / \mathrm{ml}$ ).

An affinity-purified polyclonal antibody to the vasopressin-regulated water channel, aquaporin-2, was characterized previously by DiGiovanni et al. (18). Similarly, an affinity-purified polyclonal antibody to aquaporin-3, a water channel found in the plasma membranes of collecting duct cells, was characterized previously by Ecelbarger et al. (19).

\section{Immunoblotting studies}

Preparation of membrane fractions from rat tissues. Sprague-Dawley rats (National Cancer Institute-Frederick Cancer Research Center, Frederick, MD) were killed by decapitation and tissues (lung, liver, total kidney, heart ventricle, brain cortex) were quickly removed. Approximately 1 gram of each tissue was homogenized using a tissue homogenizer (Omni 1000 fitted with a micro-sawtooth generator) in icecold isolation solution ( $250 \mathrm{mM}$ sucrose, $10 \mathrm{mM}$ triethanolamine) with added protease inhibitors leupeptin $(1 \mu \mathrm{g} / \mathrm{ml}$; Bachem California, Torrance, CA) and phenylmethyl sulfonyl fluoride $(0.1 \mathrm{mg} / \mathrm{ml}$; United States Biochemical Corporation, Toledo, $\mathrm{OH}$ ). The homogenates were initially spun at low speed $(800 \mathrm{~g})$ for $10 \mathrm{~min}$ to pellet incompletely homogenized fragments and nuclei. The supernatants were then spun at 17,000 $\mathrm{g}$ for $20 \mathrm{~min}$ in a Sorvall RC2-B centrifuge with an SS34 rotor to obtain a membrane fraction enriched in plasma membranes (5). The pellets were resuspended in isolation solution with protease inhibitors and the total protein concentration was measured using the Pierce BCA Protein Assay Reagent kit.

Preparation of IMCD suspensions. A cell suspension enriched in IMCD cells was prepared using a technique described by Stokes et al. (20) as modified by Chou et al. (21). Inner medullas were removed from kidneys of six Sprague-Dawley rats and were minced finely with a razor blade. The minced tissue was transferred into $8 \mathrm{ml}$ of bicarbonate buffer solution $(125 \mathrm{mM} \mathrm{NaCl} ; 25 \mathrm{mM} \mathrm{NaHCO} ; 2 \mathrm{mM}$ $\mathrm{K}_{2} \mathrm{HPO}_{4} ; 1.2 \mathrm{mM} \mathrm{MgSO}_{4} ; 2 \mathrm{mM} \mathrm{CaCl} ; 5.5 \mathrm{mM}$ glucose; $5 \mathrm{mM} \mathrm{Na}$ acetate; $6 \mathrm{mM}$ L-alanine) with $2 \mathrm{mg} / \mathrm{ml}$ collagenase $\mathrm{B}$ and $0.7 \mathrm{mg} / \mathrm{ml}$ hyaluronidase. The tissue was incubated at $37^{\circ} \mathrm{C}$ with $\mathrm{CO}_{2} /$ air superfusion for $60 \mathrm{~min}$. Every $15 \mathrm{~min}$ the cells were aspirated through a broad-tip Pasteur pipette 10-12 times to break up clumps of cells. After addition of $0.001 \%$ DNase, samples were incubated at $37^{\circ} \mathrm{C}$ for another $20 \mathrm{~min}$. After removing an aliquot ("whole inner medulla"), the resulting cell suspension was centrifuged at $50 \mathrm{~g}$ and the supernatant, containing most of the thin limb segments and small blood vessels, was discarded. This procedure was repeated twice, resulting in a suspension that consisted almost entirely of small collecting duct fragments with very few thin limbs. After the final spin, the cells were resuspended in isolation solution with protease inhibitors (see above) and homogenized as above. The homogenate was subjected to a limited subcellular fractionation procedure as follows. An initial spin was carried out at $800 \mathrm{~g}$ in a Tomy centrifuge (TMA-3E rotor) to remove nuclei and incompletely homogenized cellular debris. The supernatant was then spun at 17,000 $g$ for $20 \mathrm{~min}$ as described above to yield a membrane fraction enriched in plasma membranes $(5,19)$. The $17,000 \mathrm{~g}$ supernatant was either retained or subjected to a further high speed centrifugation $(200,000 \mathrm{~g}$ for $60 \mathrm{~min}$ in a Beckman L8-M ultracentrifuge with an $80 \mathrm{TI}$ rotor) to obtain a low density microsome fraction enriched in intracellular vesicles. The total protein concentrations of all fractions were measured using the Pierce BCA Protein Assay Reagent kit.

Electrophoresis and immunoblotting of membranes. The membrane fractions were solubilized at $60^{\circ} \mathrm{C}$ for $15 \mathrm{~min}$ in Laemmli buffer and SDS/PAGE was carried out on minigels of $12 \%$ polyacrylamide (Novex, San Diego, CA). The proteins were transferred from the gels electrophoretically to nitrocellulose membranes using a Bio Rad transfer apparatus (Bio Rad Laboratories, Hercules, CA). After blocking with 50 grams/liter nonfat dry milk in wash buffer $(150 \mathrm{mM}$ $\mathrm{NaCl}, 50 \mathrm{mM} \mathrm{NaH}_{2} \mathrm{PO}_{4}, 50 \mathrm{mg} / \mathrm{dl}$ Tween-20, $\mathrm{pH}$ 7.25), the nitrocellulose membranes were probed with the affinity-purified polyclonal antibody to the syntaxin- 4 at IgG concentration of $0.5 \mu \mathrm{g} / \mathrm{ml}$ in antibody dilution buffer solution $\left(150 \mathrm{mM} \mathrm{NaCl}, 50 \mathrm{mM}\right.$ sodium $\mathrm{NaH}_{2} \mathrm{PO}_{4}, 100$ $\mathrm{mg} /$ liter sodium azide, $50 \mathrm{mg} / \mathrm{liter}$ Tween-20, 10 grams/liter bovine serum albumin; $\mathrm{pH} 7.5)$. The secondary antibody was donkey anti-rabbit IgG conjugated to horseradish peroxidase (Pierce No. 31458) used at a concentration of $0.16 \mu \mathrm{g} / \mathrm{ml}$ in the antibody dilution buffer solution. Sites of antibody-antigen reaction were visualized using Luminol-based enhanced chemiluminescence (LumiGLO; Kirkegaard and Perry Laboratories, Gaithersburg, MD) before exposure to light-sensitive imaging film (Kodak No. 165-1579 Scientific Imaging Film). Controls were carried out, as described in Results, using the IgG fraction of the preimmune serum and affinity-purified antiserum preadsorbed with the immunizing peptide.

\section{Immunocytochemistry}

Male Wistar rats (Mollegaard Breeding Centre, Denmark), weighing 250-300 grams, were anesthetized with intraperitoneal sodium pentobarbital, and the kidneys were perfused retrograde via the abdominal aorta with ice-cold fixative ( $4 \%$ paraformaldehyde in $0.1 \mathrm{M} \mathrm{Na}$ cacodylate buffer, $\mathrm{pH}$ 7.4) for $3 \mathrm{~min}$. The kidneys were then removed and prepared for immunochemistry. Tissue blocks were cut from inner medulla with a razor blade. They were postfixed for $2 \mathrm{~h}$ in $4 \%$ paraformaldehyde, and then infiltrated with $2.3 \mathrm{M}$ sucrose $/ 2 \%$ paraformaldehyde for $30 \mathrm{~min}$. The blocks were then mounted on holders and rapidly frozen in liquid nitrogen.

Thin $(0.85 \mu \mathrm{m})$ cryosections, cut on a Reichert Ultracut FCS cryo-ultramicrotome, were incubated with the affinity-purified antibodies against syntaxin- $4(0.7-2.8 \mu \mathrm{g} \mathrm{IgG} / \mathrm{ml})$ as described previously (10). The labeling was visualized using horseradish peroxidase-conjugated secondary antibodies (DAKO P448, 1:100, DAKO A/S, Glostrup, Denmark). Controls using preimmune serum, nonimmune IgG, or omission of primary or secondary antibody revealed no labeling.

\section{RT-PCR amplification of syntaxin $m R N A s$}

RT-PCR experiments were carried out to localize syntaxin mRNAs in (a) total RNA samples extracted from various tissues or $(b)$ from microdissected renal tubule segments and vascular elements.

$R T$-PCR using total RNA samples. To assess syntaxin- 4 mRNA expression in various organs, total RNA samples were prepared from several tissues (heart ventricle, lung, liver, brain cortex, total kidney) 


\begin{tabular}{|c|c|c|c|c|c|}
\hline & Position & Antisense sequence $\left(5^{\prime}-3^{\prime}\right)$ & Position & Sense primer $\left(5^{\prime}-3^{\prime}\right)$ & $\begin{array}{l}\text { Expected length } \\
\text { (bp) }\end{array}$ \\
\hline Syn-1A & 1083-1102 & TGCTCCССТCTGCCTCCTGT & $530-552$ & TTGCCTCTGGGATCATCATGGAC & 573 \\
\hline Syn-1B & 953-975 & CTGGGTCTGTTTTGGGAGTGAGC & $548-570$ & ACTCGCAGATGACAAAGCAAGCC & 428 \\
\hline Syn-4 & $859-882$ & GGTGATGCCAATGATGACAGCCAA & 6-28 & CGACAGGACCCATGAGTTGAGGC & 877 \\
\hline Aquaporin-2 & $1111-1131$ & TAAGCACAGTCCCCCAGAAGG & $570-588$ & TCCAGCAGTTGTCACTGGC & 562 \\
\hline
\end{tabular}

Positions of the primers are numbered from the ATG initiation codon of the syntaxin cDNA sequences reported by Bennett et al. (14) and of the AQP-2 cDNA sequence reported by Fushimi et al. (33).

or from the major regions of the kidney (IM, outer medulla [OM], and cortex [C]) using a method adapted from that of Chomczynski and Sacchi (22). Sprague-Dawley rats were killed by decapitation and both kidneys were removed. 100-200 mg of each tissue was homogenized in $4 \mathrm{ml}$ of RNAzol (4 M guanidium thiocyanate, $25 \mathrm{mM}$ disodium-citrate, $\mathrm{pH}$ 7.0) containing $3.6 \mu \mathrm{l} / \mathrm{ml} \beta$-mercaptoethanol. RNAs were extracted using chloroform, purified by isopropanol precipitation, and washed with $70 \%$ ethanol. Then, the RNA pellets were resuspended in $200 \mu$ l of RNA dilution buffer and stored at $-80^{\circ} \mathrm{C}$ until use for RT-PCR. The RNA dilution buffer contained $10 \mathrm{mM}$ Tris (pH 7.5), $0.1 \mathrm{mM}$ EDTA, $2 \mathrm{mM}$ DTT, and $40 \mathrm{U} / \mathrm{ml}$ RNase inhibitor (Boehringer-Mannheim, Indianapolis, IN).

Primers corresponding to syntaxin-1A, syntaxin-1B, and syntaxin- 4 were chosen (Table I) with the aid of the computer program OLIGO 5.0 (National Biosciences, Plymouth, MN). The chief criteria were: specificity, $\mathrm{T}_{\mathrm{m}}$ close to $60^{\circ} \mathrm{C}$, lack of predicted internal structure. In general the sense primers were located in the coding region whereas the antisense primers were in the 3 '-untranslated region. RT-PCR reactions were performed as described previously (23). Briefly, RT was carried out with the antisense primer $(6.25 \mathrm{pmol})$ in a $50-\mu l$ reaction volume containing $20 \mathrm{mM}$ Tris- $\mathrm{HCl}(\mathrm{pH} 8.3), 50 \mathrm{mM} \mathrm{KCl}, 3.5 \mathrm{mM}$ $\mathrm{MgCl}_{2}, 200 \mu \mathrm{M}$ of each deoxynucleotide triphosphate, $6.4 \mathrm{mM}$ DTT, $0.1 \mathrm{mg} / \mathrm{ml}$ gelatin, and $200 \mathrm{U}$ of MMLV reverse transcriptase (Life Technologies, Gaithersburg, MD). Each reaction used $2 \mu \mathrm{g}$ of total

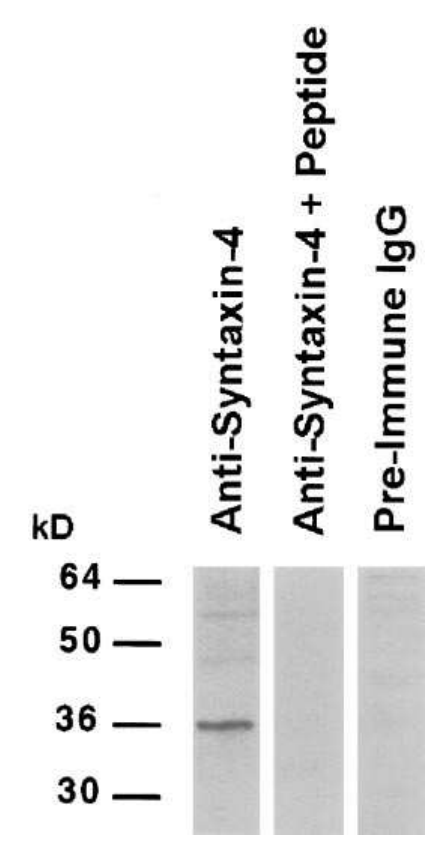

Figure 1. Labeling of a $36-\mathrm{kD}$ protein from IMCD cells with anti-syntaxin-4 antibody. SDSPAGE was run using $10 \mu \mathrm{g}$ protein from membrane fraction $(17,000 \mathrm{~g}$ pellet) from rat IMCD cell suspension and proteins were transferred to nitrocellulose membranes. Blots were probed with affinity-purified anti-syntaxin- 4 antibody at $\operatorname{IgG}$ concentration $0.56 \mu \mathrm{g} / \mathrm{ml}$ (left), with the same antibody preincubated with $2 \mathrm{mg}$ of the immunizing peptide covalently attached to agarose beads (center), and with an $\mathrm{IgG}$ fraction from the preimmune serum at the same IgG concentration used for antisyntaxin-4 blot (right). Anti-syntaxin-4 antibody (left) was preexposed to agarose beads without the attached peptide to control for possible nonspecific binding of specific IgG in preadsorption control.
RNA. After completion of RT $\left(45 \mathrm{~min}, 42^{\circ} \mathrm{C}\right)$, the temperature was raised to $96^{\circ} \mathrm{C}$ for $30 \mathrm{~s}$ to inactivate the enzyme and denature the RNA-cDNA hybrids, then lowered to $80^{\circ} \mathrm{C}$. PCR was initiated by adding $50 \mu \mathrm{l}$ of a mix containing $20 \mathrm{mM}$ Tris- $\mathrm{HCl}(\mathrm{pH} 8.3), 50 \mathrm{mM}$ $\mathrm{KCl}, 0.1 \mathrm{mg} / \mathrm{ml}$ gelatin, $1.25 \mathrm{U}$ of $\mathrm{Taq}$ polymerase (Perkin-Elmer Corp., Norwalk, CT) and the appropriate sense primer (6.25 pmol). In addition, either 2.5 or $3.5 \mathrm{mM} \mathrm{MgCl}_{2}$ was used as designated in the figure captions. The samples were overlaid with mineral oil and processed for 31 cycles $\left(96^{\circ} \mathrm{C}\right.$ for $30 \mathrm{~s} ; 59-61^{\circ} \mathrm{C}$, depending on the primers, for $30 \mathrm{~s} ; 74^{\circ} \mathrm{C}$ for $1 \mathrm{~min}$ ). At the end of the last cycle the elongation time at $74^{\circ} \mathrm{C}$ was extended to $10 \mathrm{~min} .10 \mu \mathrm{l}$ of each PCR product was electrophoresed using $1.5 \%$ agarose gels, stained with ethidium bromide, destained, and photographed.

$R T-P C R$ in isolated renal tubule segments. Renal tubule segments were microdissected as described (24) and RT-PCR was performed as described previously $(21,25)$ and as summarized briefly in the following. The rats were killed by decapitation. Quickly, the left kidney was perfused with ice-cold dissection solution $(135 \mathrm{mM} \mathrm{NaCl}, 0.5 \mathrm{mM}$ $\mathrm{KCl}, 0.1 \mathrm{mM} \mathrm{Na}_{2} \mathrm{HPO}_{4}, 0.3 \mathrm{mM} \mathrm{NaC}_{3} \mathrm{COONa}, 0.12 \mathrm{mM} \mathrm{Na}_{2} \mathrm{SO}_{4}, 2.5$ $\mathrm{mM} \mathrm{CaCl}_{2}, 1.2 \mathrm{mM} \mathrm{MgSO}_{4}, 5 \mathrm{mM}$ Hepes, and $5.5 \mathrm{mM}$ glucose, at $\mathrm{pH}$ 7.4) and followed by $5 \mathrm{ml}$ of collagenase-hyaluronidase solution (10 $\mathrm{mg}$ collagenase, and 5,000 U hyaluronidase, $3 \mathrm{mg}$ BSA in $5 \mathrm{ml}$ of dissection solution). Then, the kidney was removed, sliced, and incubated in the collagenase-hyaluronidase solution at $37^{\circ} \mathrm{C}$ with continuous oxygenation for $10-40 \mathrm{~min}$. The different segments were microdissected freehand using Dumont No. 5 forceps in dissection solution containing 1:40 vanadyl ribonucleoside complex (VRC), a ribonuclease inhibitor. 1-2-mm lengths of these microdissected segments were washed in dissection solution with added $0.1 \%$ BSA but without VRC, and then transferred with $2 \mu$ l of the dissection solution with $0.1 \%$ BSA into PCR tubes containing $6.7 \mu l$ of Triton X-100 solution (mix of $96 \mu \mathrm{l}$ 2\% Triton X-100, $3.5 \mu \mathrm{l}$ RNase placental inhibitor [Boehringer-Mannheim], and $0.5 \mu \mathrm{l} 1 \mathrm{M}$ DTT). Finally, the samples were frozen on dry ice and then thawed before RT-PCR was initiated. To monitor for RNA or cDNA contamination of reagents, blanks were included in each assay with $2 \mu$ l of the wash solution in lieu of tubules.

We used the same specific primers described above (Table I). Primers specific for the aquaporin-2 water channel were also used in some reactions with collecting ducts to provide a positive control (Table I). $11.3 \mu \mathrm{l}$ of the following mix was added to each PCR tube: $4 \mu \mathrm{l}$ of $5 \times$ Boehringer-Mannheim incubation buffer, $50 \mathrm{U}$ RNase inhibitor, 20 nmol of each deoxynucleotide, $1.6 \mu \mathrm{g}$ of poly $(\mathrm{dT})_{15}$, and $50 \mathrm{U}$ of AMV reverse transcriptase (Boehringer-Mannheim). The RT was carried out for $60 \mathrm{~min}$ at $42^{\circ} \mathrm{C}$, followed by $5 \mathrm{~min}$ at $95^{\circ} \mathrm{C}$. The tubes were then placed on ice and $80 \mu \mathrm{l}$ of the following mix was added to each tube: $10 \mu \mathrm{l}$ of $10 \times$ Perkin-Elmer reaction buffer, $200 \mu \mathrm{mol}$ of each deoxynucleotide, $50 \mathrm{pmol}$ of sense and antisense specific primers, and $2.5 \mathrm{U}$ DNA polymerase (AmpliTaq; Perkin-Elmer). The samples were overlaid with mineral oil and processed for 31 cycles $\left(94^{\circ} \mathrm{C}, 1 \mathrm{~min}[3 \mathrm{~min}\right.$ for the initial cycle]; $59-61^{\circ} \mathrm{C}$ according to the primers, $1 \mathrm{~min} ; 72^{\circ} \mathrm{C}, 1 \mathrm{~min}$ ). The elongation period in the last cycle was extended to $7 \mathrm{~min} .90 \mu \mathrm{l}$ of the PCR product was precipitated by adding $1 / 10 \mathrm{vol}$ of $3 \mathrm{M} \mathrm{Na}$ ace- 


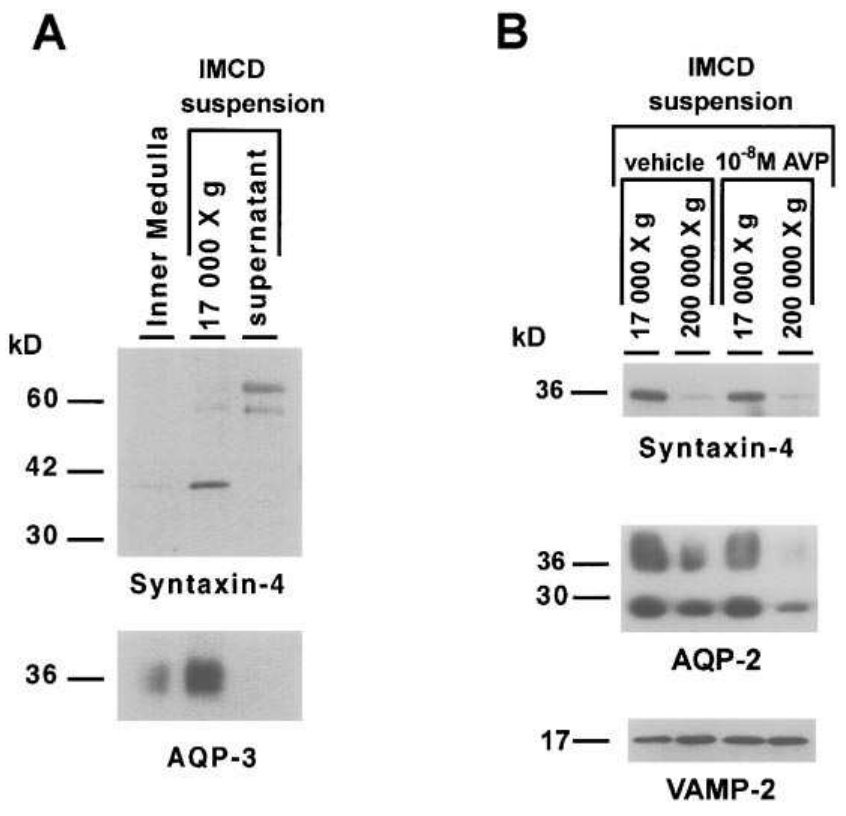

Figure 2. Syntaxin-4 immunoreactivity in subcellular fractions of IMCD cells obtained by differential centrifugation. $(A)$ Parallel enrichment of syntaxin-4 and aquaporin-3 immunoreactivity in membrane fraction of IMCD cells. Upper immunoblot was probed with anti-syntaxin-4 antibody ( $0.89 \mu \mathrm{g} / \mathrm{ml} \mathrm{IgG).} 10 \mu \mathrm{g}$ of total protein was loaded per lane. Lower immunoblot was probed with anti-aquaporin-3 (AQP-3) antibody $(0.46 \mu \mathrm{g} / \mathrm{ml} \mathrm{IgG)}$. $5 \mu \mathrm{g}$ of total protein was loaded per lane. Enrichment of immunoreactive $36-\mathrm{kD}$ protein in plasma membrane-enriched fraction $(17,000 \mathrm{~g}$ pellet) from IMCD suspension (above) parallels that of AQP-3 (below), a plasma membrane marker for collecting duct cells (19). (B) Immunoblots run with LS membrane fraction (pellet from 17,000 $\mathrm{g}$ centrifugation) and HS membrane fraction (pellet from 200,000 $\mathrm{g}$ centrifugation of 17,000 $\mathrm{g}$ supernatant) from IMCD cell suspension. Upper immunoblot was probed with anti-syntaxin- 4 antibody $(0.56 \mu \mathrm{g} / \mathrm{ml} \mathrm{IgG}) .5 \mu \mathrm{g}$ of total protein was loaded per lane. The LS membrane fraction contained substantial amounts of the immunoreactive $36-\mathrm{kD}$ protein, whereas the HS membrane fraction contained little or no immunoreactive $36-\mathrm{kD}$ protein. Middle immunoblot was probed with anti-aquaporin-2 (AQP-2) antibody $(0.077 \mu \mathrm{g} / \mathrm{ml} \mathrm{IgG}) .1 \mu \mathrm{g}$ of total protein was loaded per lane. As demonstrated previously $(5,19)$, aquaporin-2 was distributed to both LS and HS fractions and the amount in the HS fraction was decreased by vasopressin (middle). VAMP2 immunoreactivity (bottom) was seen in both LS and HS fractions and was not altered by vasopressin. $10 \mu \mathrm{g}$ total protein was loaded per lane and primary antibody was anti-VAMP2 at $0.096 \mu \mathrm{g} / \mathrm{ml} \mathrm{IgG}$.

tate ( $\mathrm{pH} 5.2)$ and $2 \mathrm{vol}$ of $100 \%$ ethanol. The pellet were washed with $70 \%$ ethanol. The samples were resuspended in $10 \mu \mathrm{l}$ of TE $(10 \mathrm{mM}$ Tris, $1 \mathrm{mM}$ EDTA, pH 7.5), electrophoresed on a $1 \%$ agarose gel, stained with ethidium bromide, destained, and photographed as described above. Selected products were sequenced commercially by a combination of direct cycle sequencing and standard sequencing of the cloned PCR product (Lofstrand Laboratories, Gaithersburg, $\mathrm{MD)}$ to confirm the identity of the amplified cDNA.

\section{Results}

Syntaxin-4 protein is expressed in renal collecting duct. We prepared a rabbit polyclonal antibody to a 23-amino acid synthetic peptide corresponding to the amino terminus of rat syn- taxin-4. This peptide was chosen to produce an antibody with a high degree of specificity for syntaxin-4 (see Discussion). Fig. 1 shows immunoblots run with crude membrane fractions prepared from rat IMCD cell suspensions and probed with the affinity-purified anti-syntaxin-4 (left), with the same antibody preadsorbed with an excess of the immunizing peptide (middle), and with the $\mathrm{IgG}$ fraction from the preimmune serum (right). The antibody labeled a distinct $36-\mathrm{kD}$ band, consistent with the expected molecular mass of syntaxin-4 (14). This band was not seen with the peptide-adsorbed antibody or with the preimmune IgG.

Fig. $2 A$ shows immunoblots prepared from SDS-polyacrylamide gels loaded with a homogenate from the whole inner medulla and with membrane fractions from an IMCD cell suspension. These were probed with the affinity-purified antibody to syntaxin-4 (upper blot) and an affinity-purified polyclonal antibody to aquaporin-3, a plasma membrane marker for collecting duct principal cells (19) (lower blot). As shown, there was a parallel enrichment of syntaxin-4 and aquaporin-3 in the $17,000 \mathrm{~g}$ fraction from IMCD cells relative to whole inner medulla, suggesting that syntaxin-4 is present in the plasma membranes of collecting duct cells.

Further differential centrifugation experiments were carried out using IMCD cell suspensions to assess the distribution of syntaxin-4 immunoreactivity between a plasma membraneenriched low-speed (LS) membrane fraction and a high-speed (HS) membrane fraction, enriched in intracellular vesicles (5) (Fig. 2 B). Syntaxin-4 (upper blot) appears to be abundant in the plasma membrane-enriched LS fraction, while little syntaxin- 4 is present in the HS membrane fraction, which contains most of the aquaporin-2-bearing intracellular vesicles (5). In contrast, aquaporin-2 was abundant in both fractions (middle blot). As previously reported (5), vasopressin shifts aquaporin-2 out of the HS fraction, presumably as a result of stimulation of exocytosis of aquaporin-2-bearing vesicles. However, vasopressin did not affect the distribution of syntaxin-4 immunoreactivity between the HS and LS fractions. As shown, in the lower blot in Fig. 2 B, VAMP-2 was also present in membrane fractions from IMCD cell suspensions. In contrast to syntaxin-4, VAMP-2 was predominantly found in the HS fraction. However, a significant amount of VAMP-2 was also present in the LS fraction, suggesting either that VAMP-2 may be present in plasma membrane or, more likely, that the LS fraction contains a substantial amount of non-plasma membrane membrane protein including VAMP-2-bearing intracellular vesicles. Unlike AQP-2, VAMP-2 was not decreased in the HS fraction in response to vasopressin.

To determine which plasma membrane domain contains syntaxin-4, we carried out immunoperoxidase labeling in thin cryosections of rat inner medulla (Fig. 3). The anti-syntaxin-4 antibody gave discrete labeling of the apical plasma membrane domain of the IMCD cells as seen both in the longitudinal section and the cross-section (Fig. 3, inset). There was no perceptible labeling of the basolateral plasma membrane. A control using preimmune IgG gave no labeling. This demonstrates that the apical plasma membrane labeling is specific for syntaxin-4 and is not associated with the weak higher molecular mass band seen in the $17,000 \mathrm{~g}$ supernatant (Fig. 2) which was present when blots were probed with preimmune serum. Therefore, these results point to the presence of syntaxin- 4 in the apical plasma membrane, the target membrane for aquaporin-2 water channel vesicles. 


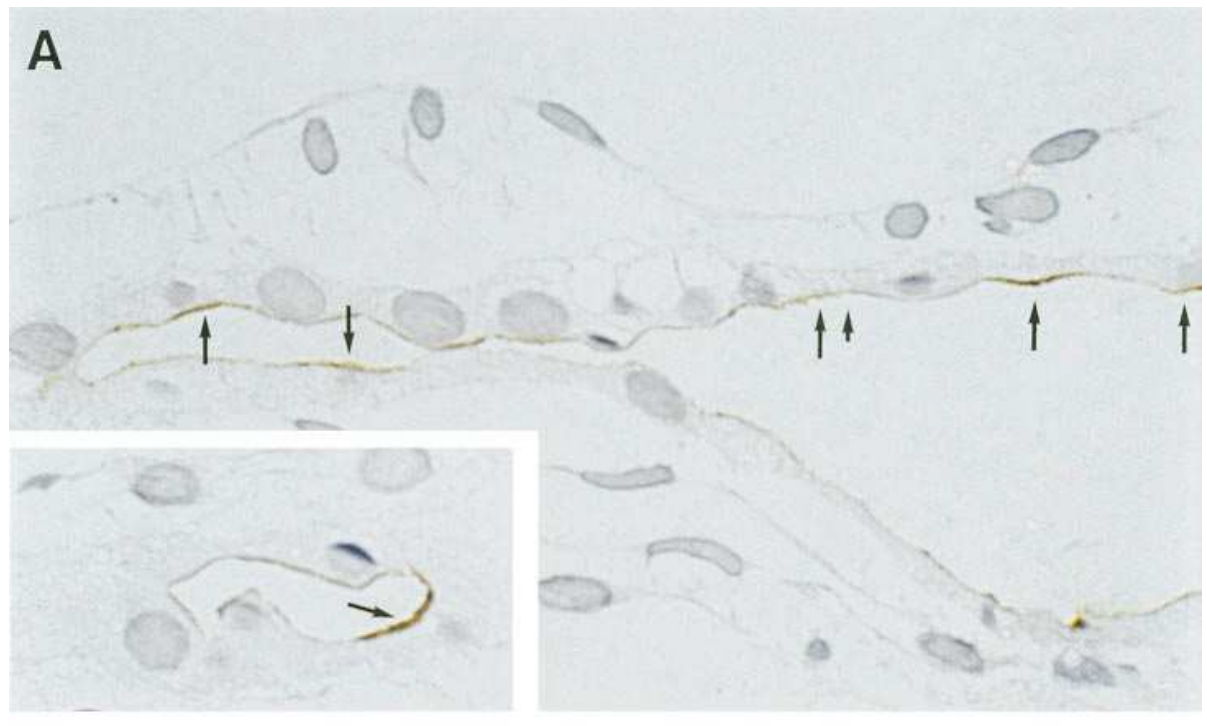

B

Figure 3. Immunocytochemical localization of syntaxin- 4 in $0.85-\mu \mathrm{m}$ cryosections of rat renal inner medulla. Sections show immunoperoxidase labeling of IMCD in a longitudinal section $(A)$ and in a crosssection (inset). $\mathrm{IgG}$ concentration of primary antibody was $1.4 \mu \mathrm{g} / \mathrm{ml}$. $B$ shows inner medullary cryosection probed with preimmune IgG at the same IgG concentration.

Syntaxin-4 $m R N A$ is expressed in renal collecting duct. To further establish the presence of syntaxin-4 expression in the renal collecting duct, we examined whether syntaxin-4 mRNA is present in collecting duct cells. RT-PCR experiments were carried out in microdissected renal tubule segments (Fig. 4). Collecting ducts from all three renal regions (CCD, OMCD, and IMCD) appear to express syntaxin- 4 mRNA. Restriction analysis of the PCR product using Pst1 gave products of sizes consistent with those predicted for syntaxin-4 (not shown). Direct sequencing of the 877-bp product yielded a sequence which was $>99 \%$ identical to that reported for rat syntaxin- 4 (14), demonstrating that the amplified cDNA in collecting ducts indeed corresponds to syntaxin-4 rather than to some other syntaxin isoform. Therefore, this result confirms the conclusion from immunoblotting and immunolocalization studies that syntaxin-4 is expressed in collecting duct principal cells. Parallel amplifications using primers for rat aquaporin-2 provided a positive control for collecting ducts, confirming that the collecting duct segments were correctly identified in the microdissection. Controls run without added tissue were uniformly negative, ruling out the possibility that the signal derives from cDNA contamination of reagents or pipettes. Con- trols run on collecting ducts without the RT step were negative, indicating that the syntaxin-4 signal derives from mRNA present in the collecting duct cells rather than from genomic DNA. In addition to substantial levels in collecting ducts, relatively high levels of syntaxin- 4 mRNA expression were also seen in glomeruli, vasa recta, thin descending limbs, cortical thick ascending limbs, and connecting tubules. Therefore, these results indicate that syntaxin-4 expression in the kidney is not limited to collecting ducts.

Distribution of syntaxin-4 protein and $m R N A$ among nonrenal tissues. Immunoblots were also run to assess the distribution of syntaxin-4 immunoreactivity among nonrenal tissues. As shown in Fig. 5, syntaxin-4 was present in membrane fractions $(17,000 \mathrm{~g}$ pellets) from lung, liver, brain, and heart. These results indicate that syntaxin- 4 protein expression is broadly distributed among epithelial and nonepithelial tissues.

Fig. 6 shows the results of RT-PCR experiments using total RNA isolated from several tissues. Syntaxin- 4 mRNA was detectable in lung, liver, brain, heart, and kidney, confirming the conclusion that syntaxin-4 mRNA is broadly expressed (14). Substantial syntaxin-4 signals were obtained in all three regions of the kidney, namely cortex, outer medulla, and inner 


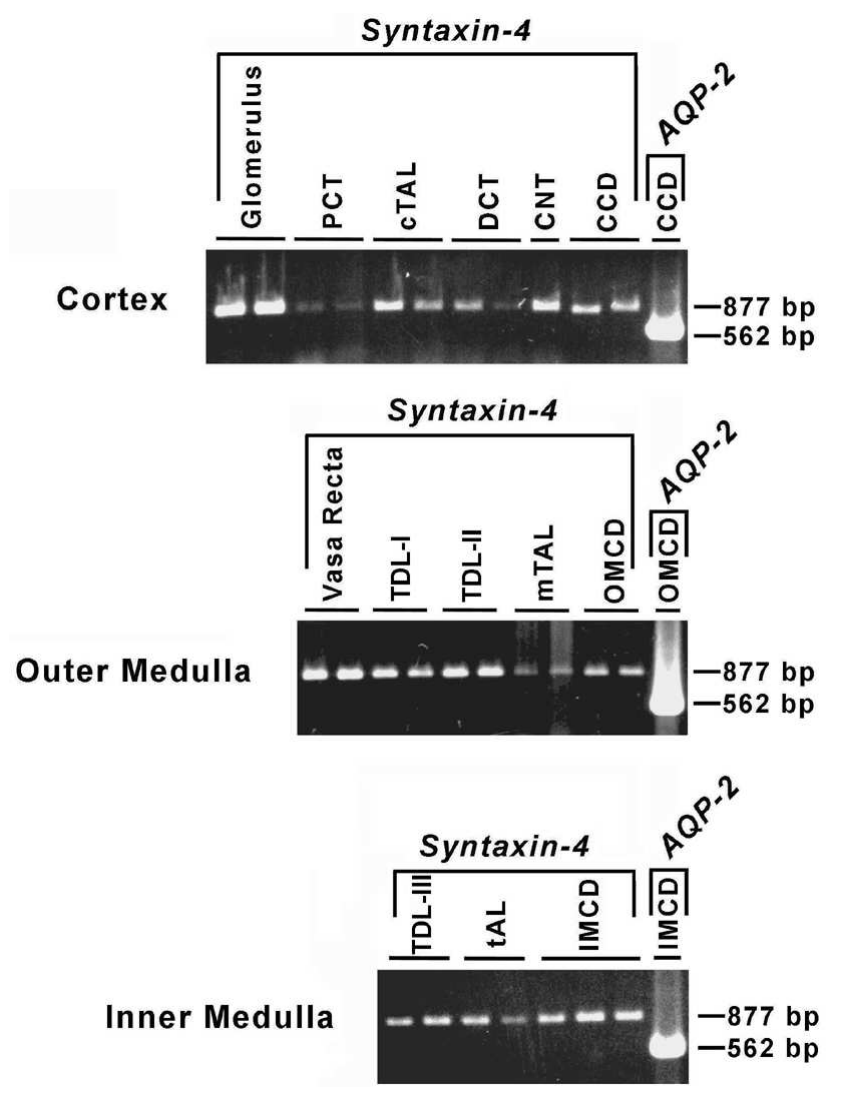

Figure 4. RT-PCR determination of relative distribution of syntaxin-4 mRNA (877 bp) in microdissected collecting ducts and other renal structures. After RT-PCR was run for 31 cycles, products were electrophoresed on $1.5 \%$ agarose gels which were stained with ethidium bromide as described in Methods. Most reactions were run in duplicate or triplicate as shown. Tissue substrate amounts for syntaxin-4 reactions: glomerulus, four tufts per sample; proximal convoluted tubule $(P C T), 2.2$ and $2.0 \mathrm{~mm}$; cortical thick ascending limb $(c T A L), 1.9$ and $1.7 \mathrm{~mm}$; distal convoluted tubule $(D C T), 2.0$ and $0.6 \mathrm{~mm}$; connecting tubule $(C N T), 1.8 \mathrm{~mm}$; $\mathrm{CCD}, 2.1$ and $2.0 \mathrm{~mm}$; vasa recta, one outer medullary vascular bundle per sample; thin descending limb type $1(T D L-I), 2.0$ and $2.5 \mathrm{~mm}$; TDL type 2 (TDL-II), 2.4 and 2.5 $\mathrm{mm}$; medullary thick ascending limb $(m T A L), 2.2$ and $2.8 \mathrm{~mm}$; OMCD, 2.2 and $2.2 \mathrm{~mm}$; inner medullary TDL type 3 (TDL-III), 3.2 and $2.8 \mathrm{~mm}$; thin ascending limb $(t A L), 2.8$ and $3.2 \mathrm{~mm}$; IMCD, 1.3, 1.3 , and $1.4 \mathrm{~mm}$. In addition, parallel reactions were run using primers for aquaporin-2 (AQP-2) in microdissected collecting ducts (562-bp product) to confirm identification of segments and success of reverse transcription step.

medulla. In parallel experiments using primers for syntaxin-1A and syntaxin-1B (not shown), a detectable band was found only in total RNA samples from the brain.

\section{Discussion}

Vasopressin (the "antidiuretic hormone"), acting via cAMP, increases the osmotic water permeability of the collecting duct principal cells by stimulating the translocation of aquaporin-2containing intracellular vesicles to the apical plasma membrane (3-6). The resulting vesicular fusion adds new aquaporin-2 water channels to the apical plasma membrane and

\section{Anti syntaxin-4 antibody}

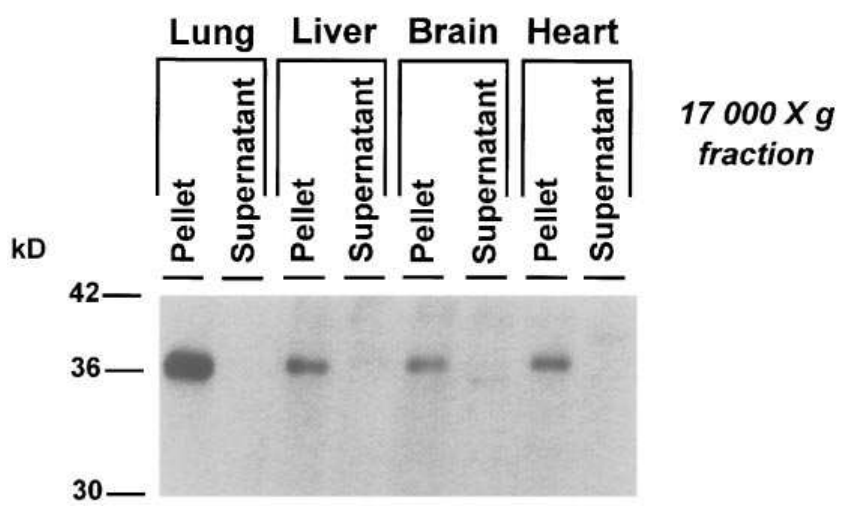

Figure 5. Distribution of syntaxin-4 immunoreactivity among various tissues. Membrane fractions $(17,000 \mathrm{~g}$ pellets) from lung, liver, brain, and heart were loaded on $12 \%$ polyacrylamide gels at $10 \mu \mathrm{g}$ protein per lane. Blot was probed with affinity-purified anti-syntaxin-4 polyclonal antibody ( $\mathrm{IgG}$ concentration, $0.56 \mu \mathrm{g} / \mathrm{ml}$ ).

thereby increases its water permeability. As is true for regulated exocytosis in other tissues, important questions remain with regard to the mechanisms by which aquaporin-2-containing vesicles are targeted to a specific membrane domain and with regard to the mechanisms by which vesicle docking and fusion are regulated. Investigation of regulated exocytosis of synaptic vesicles has recently led to a new paradigm, the socalled "SNARE hypothesis" (7), which may be useful in the analysis of regulated exocytosis in the renal collecting duct. A component of this hypothesis is the concept that specificity of vesicular targeting may be mediated by a group of membraneassociated proteins which behave as vesicle-targeting receptors

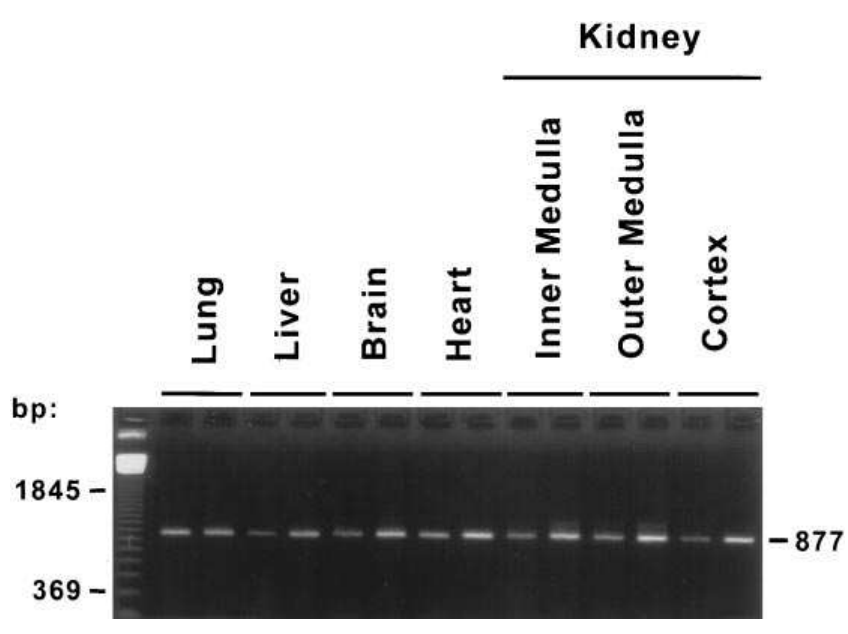

Figure 6. Distribution of syntaxin-4 mRNAs among various tissues as determined by RT-PCR. For each organ, $2 \mu \mathrm{g}$ of total RNA was loaded into each tube. Amplifications were carried out using either $2.5 \mathrm{mM}$ of $\mathrm{Mg}^{2+}$ (left lane of each pair) or $3.5 \mathrm{mM} \mathrm{Mg}^{2+}$ (right lane of each pair). After RT-PCR was run for 31 cycles, products were electrophoresed on $1.5 \%$ agarose gels which were stained with ethidium bromide as described in Methods. Predicted product size for syntaxin-4 was $877 \mathrm{bp}$. 
or SNAREs. These proteins are proposed to be associated with the vesicular membrane (vesicle-SNAREs or v-SNAREs) or with the target membrane (t-SNAREs). In this paper, we have demonstrated that a particular t-SNARE protein, syntaxin-4, is expressed in collecting duct principal cells and that its distribution within the cell is compatible with a role in targeting of aquaporin-2-containing vesicles to the apical plasma membrane.

The syntaxins are a family of integral membrane proteins of $\sim 300$ amino acids with a single membrane-spanning region near the carboxy terminus (14). In contrast to the archetypal member of the family, syntaxin-1, which is expressed chiefly in the central nervous system, syntaxin- 4 is believed to be expressed in a variety of tissues including the kidney (14). Based on indirect immunofluorescence microscopy of transfected COS cells, syntaxin- 4 is thought to be localized predominantly in the plasma membrane (14) where it has been proposed to be involved in targeting of secretory vesicles to the plasma membrane. In the current study, both subcellular fractionation experiments using differential centrifugation (Fig. 2) and immunoperoxidase localization (Fig. 3) support the view that syntaxin-4 is expressed chiefly in the plasma membrane of collecting duct cells. Furthermore, the immunoperoxidase labeling was restricted to the apical plasma membrane with no evidence of basolateral localization. Thus, the localization is fully compatible with a possible role in the targeting of aquaporin-2 vesicles to the apical plasma membrane in response to vasopressin. In previous studies we have demonstrated that a v-SNARE, VAMP2, is present in large amounts in aquaporin-2 vesicles (10), a finding also supported by Jo et al. (11) and Liebenhoff et al. (12). In vitro binding studies $(15,16)$ have demonstrated that, although VAMP2 does not bind with high affinity to syntaxin-2 and syntaxin-3, two other broadly expressed homologues, it does bind syntaxin-4 with relatively high affinity. Hence, in analogy to VAMP-syntaxin interactions that are proposed to participate in targeting of synaptic vesicles to the active zone of the presynaptic plasma membrane, we propose that VAMP2 and syntaxin-4 may fulfill a similar function in collecting duct cells to direct aquaporin-2 to the appropriate membrane domain.

Recent studies of syntaxin localization in neurons have raised doubts about the role of syntaxin as a determinant of specificity of targeting of synaptic vesicles to the active zone. Specifically, several investigators have demonstrated that immunoreactive syntaxin is present, not only in the active zone membrane, but throughout the axon (26-28). Thus, it appears that syntaxin may lack the unique localization in the neuron to allow a role in determining specificity of synaptic vesicle targeting. It appeared to us that one possible explanation for the broad distribution of immunoreactive syntaxin in the neuron could be that more than one syntaxin isoform could be recognized by the antibodies used for immunolocalization. These antibodies were raised to bacterial fusion proteins which may exhibit sequence overlap with other syntaxins. To avoid this problem, we chose a site-directed approach designed to maximize antibody specificity by immunizing with a synthetic peptide which lacks significant sequence overlap with other known syntaxins. The resulting antibody, after affinity purification, recognized a solitary band on immunoblots of renal inner medullary membranes of apparent molecular mass of 36,000 D (Fig. 1), consistent with the expected size of syntaxin-4 (14). This band was not present on blots probed with the preimmune $\operatorname{IgG}$ fraction or with the anti-syntaxin-4 antibody after preadsorption with the immunizing peptide. Both immunoblotting of membrane proteins from IMCD cell suspensions and immunocytochemistry demonstrated that this protein is present in collecting duct cells. Furthermore, RT-PCR in microdissected collecting ducts, followed by sequencing of the PCR product, confirmed the conclusion that syntaxin-4 is expressed in collecting duct cells.

Aside from the collecting duct, we found evidence from RT-PCR experiments that syntaxin- 4 mRNA is expressed in several other renal structures (Fig. 4). Constitutive membrane trafficking is a vital process in all cells and, consequently, broad distribution of syntaxins and other SNARE proteins is not an unexpected finding, assuming that the SNARE mechanism may be involved in both constitutive and regulated trafficking. Furthermore, in addition to vasopressin-regulated water channel trafficking in collecting duct cells, there are a number of other examples of regulated exocytosis in the kidney, e.g., adrenergic regulation of renin secretion and oxygenregulated erythropoietin secretion, that may use similar mechanisms of vesicular targeting.

Bennett et al. (14) observed by Northern blot analysis of various tissues that several of the syntaxins, including syntaxin-4, are widely distributed among tissues. Our results are in accord with that view. Both immunoblotting and RT-PCR experiments provided evidence for expression of syntaxin- 4 in a variety of tissues including lung, liver, heart, and brain (Figs. 5 and 6). In addition, several recent reports have documented the presence of either syntaxin-4 or its mRNA in several tissues including liver (29), pancreatic islets (30), gastric mucosa (31), and skeletal muscle (32).

In summary, we have demonstrated that at least one member of the syntaxin family, namely syntaxin-4, is expressed in the principal cells of the renal collecting duct, the site of vasopressin-regulated water transport in the kidney. Furthermore, immunoperoxidase labeling of thin cryosections showed that, within the principal cells, syntaxin-4 is localized to the apical plasma membrane. Thus, our findings have established that both VAMP2 (10) and syntaxin-4 (this paper) are in appropriate membrane domains of collecting duct cells to be involved in targeting of aquaporin-2-containing vesicles to the apical plasma membrane. These results, therefore, provide further support for the hypothesis that the SNARE mechanism could be responsible for the specificity of water channel trafficking to the apical plasma membrane in collecting duct cells.

\section{Acknowledgments}

We thank Hanne Weiling for excellent technical assistance.

Funding for this paper was derived from the intramural budget of the Heart, Lung, and Blood Institute of the National Institutes of Health, project number ZO1-HL-01282-KE (M.A. Knepper), Novo Nordic Foundation (S. Nielsen), and the Danish Medical Research Council (S. Nielsen).

\section{References}

1. Knepper, M.A., and F.C. Rector, Jr. 1995. Urinary concentration and dilution. In The Kidney. B.M. Brenner and F.C. Rector, Jr., editors. W.B. Saunders Co., Philadelphia. 532-570.

2. Knepper, M.A., S. Nielsen, C.-L. Chou, and S.R. DiGiovanni. 1994 Mechanism of vasopressin action in the renal collecting duct. Semin. Nephrol. 14:302-321.

3. Nielsen, S., C.-L. Chou, D. Marples, E.I. Christensen, B.K. Kishore, and M.A. Knepper. 1995. Vasopressin increases water permeability of kidney col- 
lecting duct by inducing translocation of aquaporin-CD water channels to plasma membrane. Proc. Natl. Acad. Sci. USA. 92:1013-1017.

4. Sabolic, I., T. Katsura, J.M. Verbabatz, and D. Brown. 1995. The AQP2 water channel: effect of vasopressin treatment, microtubule disruption, and distribution in neonatal rats. J. Membr. Biol. 143:165-177.

5. Marples, D., M.A. Knepper, E.I. Christensen, and S. Nielsen. 1995. Redistribution of aquaporin-2 water channels induced by vasopressin in rat kidney inner medullary collecting duct. Am. J. Physiol. 269:C655-C664.

6. Yamamoto, N., S. Sasaki, K. Fushimi, K. Ishibashi, E. Yaiota, K. Kawasaki, F. Marumo, and I. Kihara. 1995. Vasopressin increases AQP-CD water channel in the apical membrane of collecting duct cells without affecting AQP3 distribution in Brattleboro rat. Am. J. Physiol. 268:C1546-C1551.

7. Söllner, T., S.W. Whiteheart, M. Brunner, H. Erdjument-Bromage, S. Germanos, P. Tempst, and J.E. Rothman. 1993. SNAP receptors implicated in vesicle targeting and fusion. Nature (Lond.). 362:318-324.

8. Südhoff, T.C., P. De Camilli, H. Niemann, and R. Jahn. 1993. Membrane fusion machinery: insights from synaptic proteins. Cell. 75:1-4.

9. Bajjalieh, S.M., and R.H. Scheller. 1995. The biochemistry of neurotransmitter secretion. J. Biol. Chem. 270:1971-1974.

10. Nielsen, S., D. Marples, M. Mohtashami, N.O. Dalby, W. Trimble, and M. Knepper. 1995. Expression of VAMP2-like protein in kidney collecting duct intracellular vesicles: colocalization with aquaporin-2 water channels. J. Clin. Invest. 96:1834-1844

11. Jo, I., H.W. Harris, A.M. Amendt-Raduege, R.R. Majewski, and T.G. Hammond. 1995. Rat kidney papilla contains abundant synaptobrevin protein that participates in the fusion of antidiuretic hormone-regulated water channelcontaining endosomes in vitro. Proc. Natl. Acad. Sci. USA. 92:1876-1880.

12. Liebenhoff, U., and W. Rosenthal. 1995. Identification of Rab3-, Rab5a and synaptobrevin II-like proteins in a preparation of rat kidney vesicles containing the vasopressin-regulated water channel. FEBS Lett. 365:209-213.

13. Franki, N., F. Macaluso, W. Schubert, L. Gunther, and R.M. Hays. 1995. Water channel-carrying vesicles in the rat IMCD contain cellubrevin. Am. J. Physiol. 269:C797-C801.

14. Bennett, M.K., J.E. Garcia-Arraras, L.A. Elferink, K. Peterson, A.M. Fleming, C.D. Hazuka, and R.H. Scheller. 1993. The syntaxin family of vesicular transport receptors. Cell. 74:863-873.

15. Calakos, N., M.K. Bennett, K.E. Peterson, and R.H. Scheller. 1994. Protein-protein interactions contributing to the specificity of intracellular vesicular trafficking. Science (Wash. DC). 263:1146-1149.

16. Pevsner, J., S.-C. Hsu, J.E.A. Braun, N. Calakos, A.E. Ting, M.K. Bennett, and R.H. Scheller. 1994. Specificity and regulation of a synaptic vesicle docking complex. Neuron. 13:353-361.

17. Elferink, L.A., W.S. Trimble, and R.H. Scheller. 1989. Two vesicle-associated membrane protein genes are differentially expressed in the rat central nervous system. J. Biol. Chem. 264:11061-11064.

18. DiGiovanni, S.R., S. Nielsen, E.I. Christensen, and M.A. Knepper. 1994. Regulation of collecting duct water channel expression by vasopressin in Brattleboro rat. Proc. Natl. Acad. Sci. USA. 91:8984-8988.
19. Ecelbarger, C.A., J. Terris, G. Frindt, M. Echevarria, D. Marples, S. Nielsen, and M.A. Knepper. 1995. Aquaporin-3 water channel localization and regulation in rat kidney. Am. J. Physiol. 269:F663-F672.

20. Stokes, J.B., C. Grupp, and R.K.H. Kinne. 1987. Purification of rat papillary collecting duct cells: functional and metabolic assessment. Am. J. Physiol. 253:F251-F262.

21. Chou, C.-L., S.R. DiGiovanni, A. Luther, S.J. Lolait, and M.A. Knepper. 1995. Oxytocin as an antidiuretic hormone. II. Role of V2 vasopressin receptor. Am. J. Physiol. 268:F78-F85.

22. Chomczynski, P., and N. Sacchi. 1987. Single-step method of RNA isolation by acid guanidinium thiocyanate-phenol-chloroform extraction. Anal. Biochem. 162:156-159.

23. Elalouf, J.M., J.M. Buhler, C. Tessiot, A.C. Bellanger, I. Dublineau, and C. de Rouffignac. 1993. Predominant expression of $\beta 1$-adrenergic receptor in thick ascending limb of rat kidney. Absolute mRNA quantitation by reverse transcription and polymerase chain reaction. J. Clin. Invest. 91:264-272.

24. Wright, P.A., M.B. Burg, and M.A. Knepper. 1990. Microdissection of kidney tubule segments. In Methods in Enzymology. S. Fleischer and B. Fleischer, editors. Academic Press, San Diego. 191-231.

25. Terada, Y., T. Moriyama, B.M. Martin, M.A. Knepper, and A. GarciaPerez. 1991. RT-PCR localization of mRNA for guanylyl cyclase-coupled ANF receptor in rat kidney. Am. J. Physiol. 261:F1080-F1087.

26. Koh, S., A. Yamamoto, A. Inoue, Y. Inoue, K. Akagawa, Y. Kawamura, K. Kawamoto, and Y. Tashiro. 1993. Immunoelectron microscopic localization of the HPC-1 antigen in rat cerebellum. J. Neurocytol. 22:995-1005.

27. Sesack, S.R., and C.L. Snyder. 1995. Cellular and subcellular localization of syntaxin-like immunoreactivity in the rat striatum and cortex. Neuroscience. 67:993-1007.

28. Garcia, E.P., P.S. McPherson, T.J. Chilcote, K. Takei, and P. De Camilli. 1995. rbSec1A and B colocalize with syntaxin 1 and SNAP-25 throughout the axon, but are not in a stable complex with syntaxin. J. Cell Biol. 129:105120

29. Fujita, H., L. Locco, and A.L. Hubbard. 1995. Localization and quantitation of syntaxin 2 and 4 in rat liver and WIF-B cells. Mol. Biol. Cell. 6:183a. (Abstr.)

30. Jacobsson, G., A.J. Bean, R.H. Scheller, L. Juntti-Berggren, J.T Deeney, P.O. Berggren, and B. Meister. 1995. Identification of synaptic proteins and their isoform mRNAs in compartments of pancreatic endocrine cells. Proc. Natl. Acad. Sci. USA. 91:12487-12491.

31. Scott, D.R., S.J. Hersey, H.G. Helander, and G. Sachs. 1995. Localization of syntaxin in the chief cell of the rabbit gastric mucosa. Mol. Biol. Cell. 6 : 183a. (Abstr.)

32. Sumitani, S., T. Ramlal, Z. Liu, and A. Klip. 1995. Expression of syntaxin 4 in rat skeletal muscle and rat skeletal muscle cells in culture. Biochem. Biophys. Res. Commun. 213:462-468.

33. Fushimi, K., S. Uchida, Y. Hara, Y. Hirata, F. Marumo, and S. Sasaki. 1993. Cloning and expression of apical membrane water channel of rat kidney collecting tubule. Nature (Lond.). 361:549-552. 